\title{
Biopigments from Monascus: Strains Selection, Citrinin Production and Color Stability
}

\author{
Júlio Cesar de Carvalho ${ }^{1}$, Bruno Oliva Oishi ${ }^{1}$, Ashok Pandey ${ }^{2}$ and Carlos Ricardo Soccol ${ }^{1 *}$ \\ ${ }^{I}$ Divisão de Engenharia de Bioprocessos e Biotecnologia; Setor de Tecnologia; Universidade Federal do Paraná; \\ C. P. 19011; soccol@ufpr.br; 81531-990; Curitiba - PR - Brasil. ${ }^{2}$ Biotechnology Division; Regional Research \\ Laboaratory; CSIR; Trivandrum 695 019; India
}

\begin{abstract}
Fungi form the genus Monascus are a promising source for natural color additives. However, before effectively applying Monascus to foods, it is important to select strains which produce large amounts of biopigments but little or no citrinin, a mycotoxin usually also produced by these fungi. Also, color stability of these pigments should be properly investigated. In order to compare Monascus strains for biopigment production in solid substrate fermentation (SSF), 4 strains (NRRL 1991, NRRL 2897, CCT 3802 and LPB 31) were cultivated over PDA in Petri dishes, and compared for radial growth velocity. Also, these strains were cultivated over cooked rice, and compared in relation to their capacity to produce biopigments and citrinin. The results showed that the strain LPB 31 is the best strain for biopigment production in SSF, giving both higher pigment concentration and lower citrinin concentration on the extracts, showing that it is a promising strain for production of this bioproduct. Biopigmentassays for heat and pH stability, show that these biopigments are unstable at low pH and high temperatures, but may be successfully used at near-neutrality pH's and in non-thermal processed foods.
\end{abstract}

Key words: Monascus, biopigment, citrinin, solid-substrate fermentation

\section{INTRODUCTION}

The pigments produced by the fungus Monascus sp. are of traditional use in oriental countries, and have been subject of intense research in the last decades, because of its potential for application as food additives. The use of this color additive is not yet regulated in the European Union, United States and Brazil, among other regions. As is the case for other fungi, Monascus strains produce also mycotoxins. In this case, the mycotoxin produced is citrinin, a nephrotoxic substance which also presents antibiotic properties. Despite this toxicity problem, Monascus pigments may be quickly produced in large scale throughout the year in industrial facilities, so that it might become an industrially important pigment. The key is to find strains which produce pigments with as little citrinin as possible.

The genus Monascus (see characteristic morphology in Fig. 3) encloses three main species (M. pilosus, M. purpureus e M. ruber) belonging to the family Monascaceae and to the class Ascomyceta (Pitt, 1997), whose most important characteristic is the ability to produce secondary metabolites of polyketidic structure, (Juszlová, 1996), some of them with strong yellow, orange or red pigmentation. The two first species are more important for pigment production, while $M$. ruber is associated to the decomposition of several

* Author for correspondence 
foods. Easily found in several ecosystems, these fungi were used originally in Chine and Thailand, for the preparation of angkak, a fermented rice of strong red color which finds several uses, from conferring color to other products such as wine, cheese and meat, to medicinal uses and as meat preservative (Wong, 1981). At this moment, several industries commercialize the red, grinded rice as a natural food supplement capable of lowering blood cholesterol, while others sell the dry product or purified extracts as food colorants (Allok, 2003).
Among the pigments produced by Monascus, the red ones (Fig. 1) are regarded as the most important, because these may be used as substitutes for nitrites in meat products and for synthetic colors such as erythrosine (FD and $\mathrm{C}$ red no. 3) (Johns and Stuart, 1991, Fabre, 1993). Oriental countries such as Japan make extensive use of these pigments since decades - for an instance, as yellow water soluble pigments in candies (Watanabe, 1997), or red pigment for red rice wine.

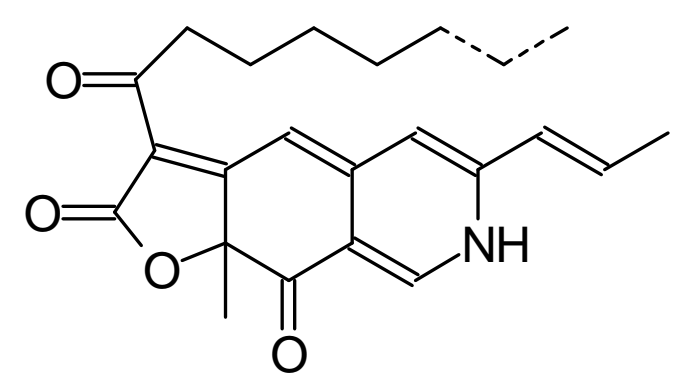

Figure 1 - Monascus sp. red pigments structure. With 7 carbon atoms in the lateral chain: monascorubramine; with 5 carbons: rubropunctatine.

The strains used for pigment production are usually isolates from Japan, China, Thailand or Indonesia, of several fermented foods: soy cheese, red koji, and the most common source, angkak (ATCC, 1987). Strains differ in the amount produced and the tone of the pigments, besides other factors such as growth velocity and overall metabolic profile. Temperature, $\mathrm{pH}$ and humidity are factors that influence the microorganism growth and pigmentation.

Excluding those that are restricted to particular research institutes, universities or companies, the strains more often cited in Monascus literature are listed below (Table 1). Notice that the same strains present several denominations, depending on the institute where it is conserved. Some of these strains were deposited with a different name than that currently accepted; the table shows the denomination in 2004, and some references related specifically to pigment production (some other strains were used for metabolic studies and antihyperlipidemics production). The growth and metabolite production of the fungi of the genus Monascus are accomplished under a number of conditions. There are several adequate culture media, but the most common are PDA and malt- extract-agar (MEA) (ATCC, 2004). The growth is possible from $15-18^{\circ} \mathrm{C}$ (minimum) to around $45^{\circ} \mathrm{C}$ (maximum) (Pitt, 1997), with the pigment production greatly varying with the species and cultivation conditions. Among the important metabolites of Monascus are the pigments, citrinin, and also a series of anti-hyperlipidemics as monacolins $\mathrm{K}$ and L (Ma, 2000). During the culturing of Monascus $\mathrm{CO}_{2}$, ethanol and acetate are also produced. While working with SSF of rice, Rosenblitt et al (2000) showed that at the end of a $240 \mathrm{~h}$ fermentation, carbon balance was as follows: ca $23 \%$ of the carbon was converted to biomass, $35 \%$ to $\mathrm{CO}_{2}, 15 \%$ to ethanol, $1 \%$ to acetic acid and $17 \%$ remained unused.

The optimal temperature range for Monascus growth is $28-32^{\circ} \mathrm{C}$, according to the registers of each species in strain banks, although this temperature varies depending on the strain between $25^{\circ} \mathrm{C}$ and $37^{\circ} \mathrm{C}$ (Lin, 1991). Growth has been observed in a wide range of $\mathrm{pH}$, from 2.5 to 8.0 , with the ideal range being from 4.0 to 7.0 (Yongsmith, 1993). There are several studies on the toxicity of Monascus pigments showing that this biopigment is apparently safe in the quantities tested. The many years for which these 
biopigments have been used suggested low or nonexistent toxicity (Lin, 1991a). When Monascus started to be studied systematically, it has been believed that the biopigments produced also presented antibiotic properties; later, it was verified that this activity is due mainly to other substance, named monascidin A (Wong, 1981). Further studies showed that this substance was, in fact, citrinin (Blanc et al., 1995a), but that not all Monascus strains produced it. It was also found that the nitrogen source used could interfere in the citrinin production.

Table 1 - Strains more often used in Monascus pigments research, origin, synonym and some references.

\begin{tabular}{|c|c|c|}
\hline Strain & Species, origin and depositor & References \\
\hline $\begin{array}{l}\text { ATCC16360, CBS 283.34, } \\
\text { ATCC 26311, IFO } 4478\end{array}$ & $\begin{array}{l}\text { Monascus purpureus Went, deposited at CBS. } \\
\text { Isolated from Angkak (fermented rice) }\end{array}$ & Miyake et al., 1984 \\
\hline $\begin{array}{l}\text { ATCC 16362, CBS 285.34, } \\
\text { ATCC 36927, DSM 1603, } \\
\text { IFO } 4485\end{array}$ & $\begin{array}{l}\text { Monascus purpureus Went, deposited at CBS. } \\
\text { Isolated from Angkak (fermented rice) }\end{array}$ & $\begin{array}{l}\text { Sheperd and Carels, } 1979 \\
\text { Rosenblitt et al. 2000. }\end{array}$ \\
\hline $\begin{array}{l}\text { ATCC 16365, CBS 109.07, } \\
\text { ATCC 16426, IFO 4513, IMI } \\
\text { 210765, NRRL } 1596\end{array}$ & $\begin{array}{l}\text { Monascus purpureus Went, deposited at CBS. } \\
\text { Isolated from Angkak (fermented rice), Java }\end{array}$ & $\begin{array}{l}\text { Sheperd and Carels, } 1979 \\
\text { Miyake et al., } 1984\end{array}$ \\
\hline $\begin{array}{l}\text { ATCC } 16367, \text { CBS } 288.34, \\
\text { DSM 1604, IFO } 4484\end{array}$ & $\begin{array}{l}\text { Monascus purpureus Went, deposited at CBS. } \\
\text { Isolated from kyokusi (fermented yeast mass, } \\
\text { China) }\end{array}$ & 979 \\
\hline ATCC 16427, NRRL 2897 & cus purpureus Went, deposited at NRRL. & $\begin{array}{l}\text { Sheperd and Carels, } 1979 \\
\text { Broder and Koehler, } 1980 .\end{array}$ \\
\hline ATCC 16435, NRRL 1991 & $\begin{array}{l}\text { Monascus sp. deposited at NRRL. Isolated from } \\
\text { koji for red rice wine, China. }\end{array}$ & Sheperd and Carels, 1979 \\
\hline $\begin{array}{l}\text { ATCC 36928, IFO } 6540, \\
\text { CCT } 3802\end{array}$ & Monascus purpureus Went, deposited at IFO. & $\begin{array}{l}\text { Yamaguchi et al. } \\
\text { Miyake et al., } \\
\text { Miyashira et al., } 2003\end{array}$ \\
\hline ATCC 96218 & $\begin{array}{l}\text { Mone } \\
\text { PJ Bl }\end{array}$ & $\begin{array}{l}\text { Santerre et al., } 1994 \text { Fabre et } \\
\text { al., } 1993\end{array}$ \\
\hline
\end{tabular}

Source: ATCC, March 2004.

As an example, for the same strain of $M$. ruber in a synthetic medium with ethanol, citrinin production ranged from $0 \mathrm{mg} / \mathrm{L}$ using methionine as nitrogen source, to $100 \mathrm{mg} / \mathrm{L}$ using ammonium nitrate as a nitrogen source (Blanc, 1995). Finally, studies over the toxicity of purified fractions of pigments showed that there was indeed an antibiotic activity for Monascus biopigments, especially the orange ones and, in lower degree, the red ones (Martínková, 1995).

Citrinin is a fungal metabolite known since 1931, when it was isolated from Penicillium citrinum and later from the Australian plant Crotolaria crispata. Ten years later it was characterized as an antibiotic and antibacterial, and later on tested for activity against bacteriophages, sarcomas, protozoa, animal cells and superior plant cells (Betina, 1984). Citrinin structure is illustrated in Fig. 2. Citrinin present a highly acidic character, is practically insoluble in water, soluble in hot alcohol, dioxane and other non polar solvents. Due to its conjugated double bonds, citrinin absorbs light in the visible wavelength range - its color varies from lemon yellow at $\mathrm{pH} \mathrm{4,6} \mathrm{to} \mathrm{cherry} \mathrm{red}$ at $\mathrm{pH} \mathrm{9,9} \mathrm{-} \mathrm{and} \mathrm{its} \mathrm{absorption} \mathrm{maxima} \mathrm{are} \mathrm{in} \mathrm{the} \mathrm{in}$ the uv range: $250-331 \mathrm{~nm}$. It presents a melting point of $175^{\circ} \mathrm{C}$ and molecular mass $250.25 \mathrm{~g} / \mathrm{mol}$ (Merck, 1996). Citrinin may be extracted with non polar solvents.

Derivatives of citrinin such as decarboxycitrinin have unknown metabolic function, but several studies in systems in vivo and in vitro indicate that citrinin itself has an biological action by inhibition of cholesterol and triglyceride synthesis, this inhibition being possibly caused by damage to transport systems and/or interferences in energetic metabolism (Betina, 1984).

The majority of Monascus researchers estimate the production of pigments by spectrophotometry, with pigment production varying from hundreds of absorbance units per $\mathrm{mL}$ culture medium, in submerged fermentations, to thousands of absorbance units/g dry substrate, in SSF (Kim et al, 2002; Lin and Demain, 1992). Experiments 
may be compared by relative production, in a 0 $100 \%$ scale.

Surprisingly, relatively few articles deal with stability of Monascus preparations, considering that several industries produce this pigment. According to Lin and Demain (1992), these pigments are reasonably stable to autoclaving, in a wide range of $\mathrm{pH}$. According to Fabre (1993), sauces and pâtés colored with red Monascus pigments show a residual color of 92 to $98 \%$ after three months at $4^{\circ} \mathrm{C}$, with good sensorial acceptance. However, these pigments are unstable towards light (only 20\% residual color after 50 days) and heat $(45 \%$ residual color after $2 \mathrm{~h}$ at $100^{\circ} \mathrm{C}$ ). These pigments are more stable under basic or neutral pH (Fabre 1993, Lee 2000).<smiles>CC1=C2C(=CO[C@@H](C)[C@@H]2C)C(O)=C(C(=O)O)C1=O</smiles>

Figure 2 - Citrinin structure

The aim of this work is to compare different Monascus strains for their biopigment and citrinin production, and also investigate Monascus biopigments stability, in order to provide information for further development of a biopigment preparation with low toxicity.

\section{MATERIAL AND METHODS}

All the experiments were performed at the "Divisão de Engenharia de Bioprocessos and Biotecnologia" (DEBB) at UFPR.

Strains used - Four Monascus strains were used in this work: two strains from United States Department of Agriculture, NRRL 1991 (Monascus. sp) and NRRL 2897 (M. purpureus), one strain from Fundação André Tosello (Brazil), CCT 3802 (M. purpureus), and LPB 31, a strain isolated at LPB from rice contaminated with red mycelium. The strains were conserved by routine inoculation and incubation in PDA at $30-32^{\circ} \mathrm{C}$ for 10 days, and then conserved by refrigeration for 3 to 4 months.

Radial growth determination - Radial growth of the strains was measured by inoculating PDA on Petri dishes with each strain, in a point on the center of the dish, in duplicate ( 8 dishes). The cultures were then incubated at $30^{\circ} \mathrm{C}$ for 12 days. The radius of the colonies was measured with a ruler, from the center of the dish, along 2 perpendicular axes (4 measures by dish) at intervals of approximately $24 \mathrm{~h}$. The values obtained were used to calculate average values (arithmetic means) of radius $\mathrm{x}$ incubation time.

Medium and inoculation for pigment comparison Inoculum was prepared immediately before use, obtained from the stock cultures by inoculation, over sterile PDA in Petri dishes, and incubated for 8 to 10 days. After incubation, a spore suspension was prepared by addition of $5 \mathrm{~mL}$ of Tween 80 at $0.1 \%$, directly over the Petri dishes, using a Drigalski hook. The spore suspensions were standardized to $1.10^{6}$ spores $/ \mathrm{mL}$ by addition of sterile water, counting also as "spores" intact mycelial fragments. The count was performed using a Neubauer chamber (on a microscope). The inoculum $(0.5 \mathrm{~mL}$ of spores suspension) was transferred to $600 \mathrm{~mL}$ fermentation flasks using sterile pipettes, and then homogenizing the medium (10g of rice with $56 \%$ humidity, or $10 \mathrm{~g}$ of cassava bagasse with $70 \%$ humidity, with $\mathrm{pH}$ adjusted to 6,5 and autoclaved for $15 \mathrm{~min}$ at $121^{\circ} \mathrm{C}$ ). These flasks were incubated at $30-32^{\circ} \mathrm{C}$ for 8 days, then dried and the content of citrinin and pigments was determined.

Pigment extraction and analysis - Monascus biopigments were extracted from fermented media using as solvent $95 \%$ ethanol, with the proportion of $5 \mathrm{~mL}$ ethanol:g dry fermented mass, with 
occasional agitation, for $24 \mathrm{~h}$, then centrifuging for $15 \mathrm{~min}$ at $10000 \mathrm{~g}$. The extracts were diluted and the absorbance was measured against pure solvent at $500 \mathrm{~nm}$, near the absorbance peak of red pigments (Johns, 1991; Lin and Demain 1992). The absorbance obtained was corrected for the dilution and dry fermentate mass, giving what we call specific absorbance, a value proportional to pigment concentration (Johns, 1991; Lin 1992; Chiu, 1993). In order to compare different strains, absorbance was translated into relative $(0-100 \%)$ absorbance.

Citrinin extraction and analysis - This analysis was made only for rice fermentations. After drying the fermentate, $5 \mathrm{~g}$ of the homogenized material was extracted with $50 \mathrm{~mL}$ of water, under agitation at $100 \mathrm{rpm}$ for 1 hour. The liquid phase was filtered, extracted twice with ethyl acetate and analyzed in accordance to Blanc et al. (1995a), using a $\mathrm{C}_{18}$ HPLC column and a PDA detector.

Biomass for stability analysis - These pigments were extracted from fresh mycelium of a submerged fermentation, in an attempt to avoid contamination with material extracted from the substrate. The fermentation was performed in a Bio-Flo fermenter with $12 \mathrm{~L}$ of liquid medium, with an aeration of 10 liters/minute, $100 \mathrm{rpm}$ agitation, incubated at $32^{\circ} \mathrm{C}$ for 10 days. The medium used was that of Lin e Demain (1991).

Biomass separation - After cultivation, the fermented broth was filtered trough cotton cloth, the biomass was washed with deionized water, drained and stored at $-20^{\circ} \mathrm{C}$ until use. Extract preparation - $5 \mathrm{~g}$ of stored biomass were mixed with $20 \mathrm{~g}$ of $95 \%$ ethanol. After $1 \mathrm{~h}$ extraction, with periodic agitation, the mixture was filtered trough a $0,47 \mu \mathrm{m}$ membrane, and the filtrate was used as a raw pigment extract.

Pigment solutions - $5 \mathrm{~mL}$ of the raw alcoholic extracts were diluted in enough water to complete $500 \mathrm{~g}$. From this solution, other solutions were prepared, with $\mathrm{pH}$ adjusted to several values, from 4 to 8 , by the addition of concentrated $\mathrm{NaOH}$ or $\mathrm{HCl}$ solutions. The dilution caused by acid/base addition was of the order of $0,5 \% \mathrm{w} / \mathrm{w}$. An alcoholic solution was prepared in a similar manner, diluting $1 \mathrm{~mL}$ of an alcoholic extract in $95 \%$ ethyl alcohol to a $100 \mathrm{~mL}$ final volume.

Stability analysis - The aqueous and alcoholic solutions were stored in stoppered glass tubes with same size and absorbance (as determined by prior absorbance analysis). These solutions were incubated at different temperatures for several hours. The color intensity was read as absorbance at $500 \mathrm{~nm}$, directly for each tube, against water as blank. The results were normalized by dividing the obtained absorbance for each tube, all along incubation time, by the initial absorbance of the same tube.

\section{RESULTS AND DISCUSSION}

Microorganism isolation and characterization The strain LPB 31 was isolated from rice contaminated with red mycelium. A portion of this mycelium was carefully extracted and inoculated in PDA in a test tube and incubated at $28^{\circ} \mathrm{C}$ for 5 days. After this step, a portion of the mycelium in the test tube was inoculated in another sterile tube, and the process was repeated until a morphologically homogeneous culture was obtained. The observation of this culture shows that the isolated microorganism isolated presents the characteristics typical to Monascus cultures: planar colonies, with some aerial development, mycelium initially white, turning to the characteristic brownish red color with time (from the center to the borders), with diffusion of the pigments through the agar. Fig. 3a shows a PDA Petri dish with some colonies well developed. Notice the diffusion halo, and the flocculent aspect of the aerial mycelium.

Microscopical exam of the colonies show a mycelium with brownish red pigmentation, cleistotechia with thin walls and hyaline ascospores with round appearance. Fig. 3b shows an isolated portion of the aerial mycelium, with formation of terminal aleurioconidia, pyriform and isolated. Fig. 3c shows two cleistotechia, one intact and another ruptured, with liberation of spores. The aspect of the isolated strain is also similar to other Monascus species, including in the formation of pigments of characteristic color. Fig. 4 shows the 4 Monascus strains used in this work, incubated at $30-32^{\circ} \mathrm{C}$.

Strain comparison - The four Monascus strains used in this work were compared regarding growth velocity in PDA, measured through radial growth (Fig. 4) and also regarding red pigment production in rice and cassava bagasse, after 7 and 11 days of fermentation, respectively.

Analysis of Fig. 4 shows that strains 1991, 2897 and LPB 31 develop in a comparable manner, with colonies slightly larger for LPB 31, while the 
strain 3802 presents colonies $30 \%$ smaller. The growth velocity, determined from the same data, show that the isolated strain, LPB 31, presents a growth velocity similar to strains NRRL 2897 and
NRRL 1991, and superior to the strain CCT 3802 (Table 2).

a

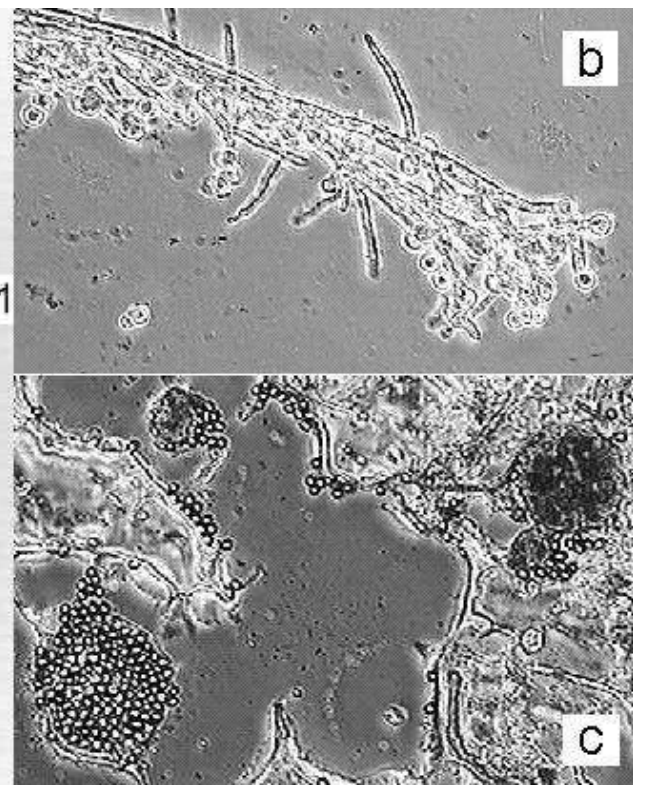

Figure 3 - (a) macroscopic aspect of four strains and (b, c) microscopic aspect of LPB31, with 400 times enlargement, after 8 days in PDA at $30-32^{\circ} \mathrm{C}$

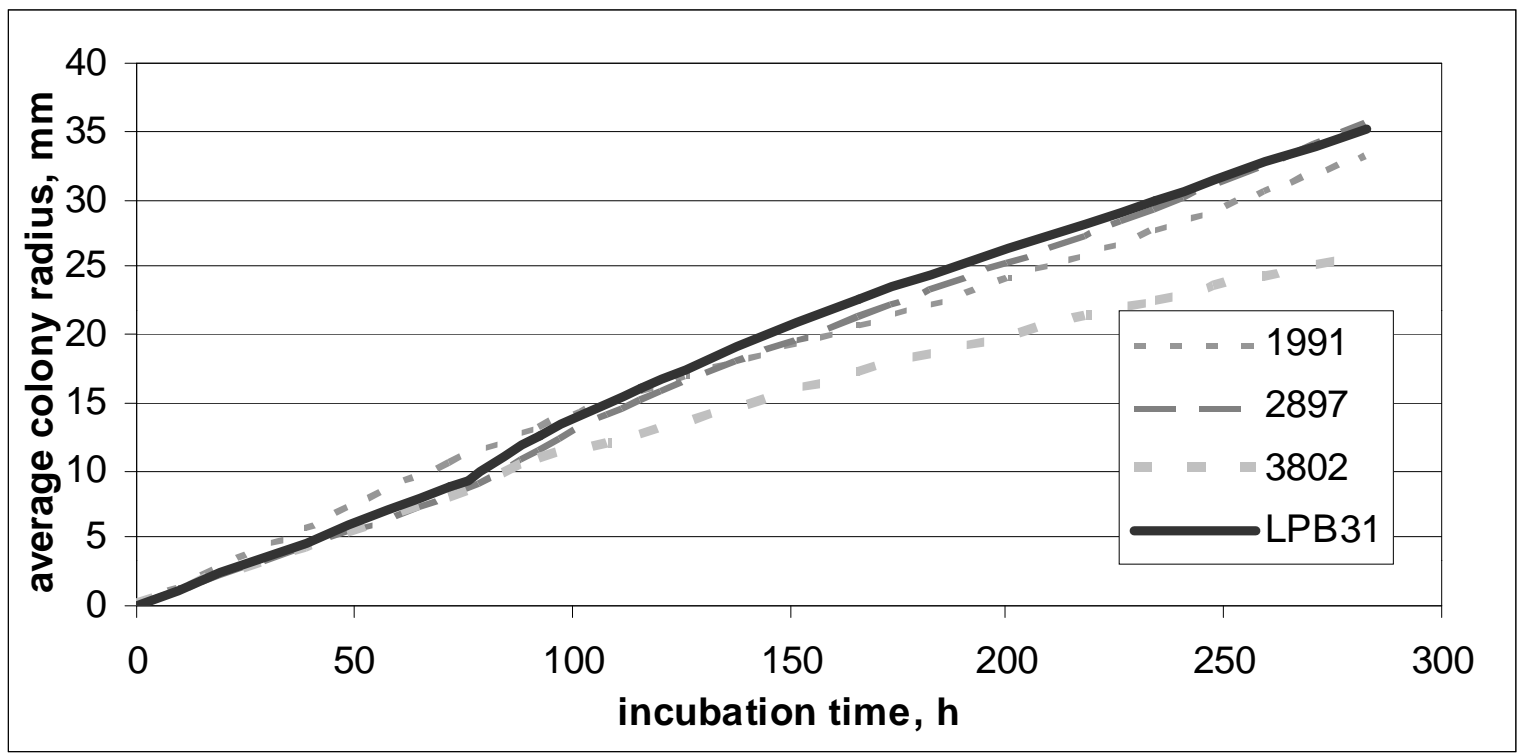

Figure 4 - colony mean radius $(\mathrm{mm}) \mathrm{x}$ incubation time $(\mathrm{h})$ for the compared strains 
Table 2 - Growth, biopigment production and citrinin production by the tested strains, after 7 days incubation (rice) and 11 days (cassava bagasse, $\mathrm{CB}$ )

\begin{tabular}{l|c|c|c|c|c}
\hline \multirow{2}{*}{ Strain } & $\begin{array}{c}\text { Average radial } \\
\text { growth velocity } \\
\text { (mm/day) }\end{array}$ & $\begin{array}{c}\text { Regression } \\
\text { coefficient } \\
\text { for data, R2 }\end{array}$ & \multicolumn{2}{|c|}{$\begin{array}{c}\text { Pigment production (specific } \\
\text { absorbance, AU/g dry product) }\end{array}$} & $\begin{array}{c}\text { Citrinin } \\
\text { production in rice }\end{array}$ \\
\cline { 2 - 6 } & & & $\begin{array}{c}\text { Rice, 56\% } \\
\text { humidity }\end{array}$ & $\begin{array}{c}\text { CB, 70\% } \\
\text { humidity }\end{array}$ & $\mu \mathrm{gg}$ /g dry product \\
\hline NRRL 1991 & 2,9 & 0,983 & 16,9 & 2,4 & 25 \\
\hline NRRL 2897 & 3,0 & 0,998 & 14,1 & 13,0 & 22 \\
\hline CCT3802 & 2,3 & 0,980 & 15,5 & 2,1 & 20 \\
\hline LPB 31 & 3,1 & 0,994 & 89,3 & 20,0 & 18 \\
\hline
\end{tabular}

Table 2 shows also that the isolated strain presents pigment production expressively higher than the other tested strains, in cassava bagasse and especially in rice (cassava bagasse was used because it is a traditional substrate for SSF at LPB, while rice is the traditional substrate for Monascus pigments production). Comparing the characteristics of the tested strains with others evaluated by Miyashira (2003), also in SSF using rice, it is apparent that the isolated strain, LPB 31, is superior to other Monascus strains tested, and presents pigmentation only $13 \%$ inferior to a selected commercial standard (Table 3):

Table 3 - Comparison of several strains regarding relative pigment production and productivity, and citrinin production in rice.

\begin{tabular}{l|c|c|c}
\hline \multicolumn{1}{c|}{ Strain } & $\begin{array}{c}\text { Relative } \\
\text { absorbance(500nm) }\end{array}$ & $\begin{array}{c}\text { Productivity } \\
\text { day }^{-1}\end{array}$ & $\begin{array}{c}\text { Citrinin } \\
\boldsymbol{\mu g} / \mathbf{g} \text { product }\end{array}$ \\
\hline CCT 3802 & $0,15 \mathrm{a}$ & 0,021 & 20 \\
\hline ATCC 6405 & $0,47 \mathrm{a}$ & 0,047 & 23 \\
\hline ATCC 16365 & $0,47 \mathrm{a}$ & 0,067 & 83 \\
\hline UFPE 3196 & $0,14 \mathrm{a}$ & 0,01 & 31 \\
\hline Commercial product & $1,00 \mathrm{a}$ & 0,07 & 25 \\
\hline NRRL 1991 & 0,16 & 0,023 & 22 \\
\hline NRRL 2897 & 0,14 & 0,020 & 20 \\
\hline CCT 3802 & 0,15 & 0,021 & 18 \\
\hline
\end{tabular}

a - values from Miyashira, 2003

The analysis of Table 3 show that the best strain tested is LPB 31, either in terms of relative production (inferior only to the commercial product, in roughly 13\%) or in pigment productivity, superior to the other strains, and citrinin production, the lowest among all strains. This shows that a product made using this strain may be similar to the commercial sample in terms of color, and better in terms of toxicity, with roughly $40 \%$ less citrinin than the commercial product.

Pigment stability analysis - In an attempt to estimate how stable Monascus pigments may be in several applications, different solutions of these pigments were incubated at different $\mathrm{pH}$ and temperatures. Stability was measured as relative residual absorbance. All aqueous solutions of
Monascus pigments show a smaller absorbance in the course of time, in all the tested conditions. This effect is more important in higher temperatures; Fig. 5 shows this effect for 5 pigment solutions at pH 6 (a typical value for foods), at different incubation temperatures.

The effect of temperature is similar to that observed in other thermal degradations, in which higher temperatures greatly increase the effect. However, an Arrhenius kinetic model of exponential decay does not represent the system well. This is possibly due to the fact that the extract is a mixture of pigments, whose degradation may present different decaying behavior. It is clear, however, that color alterations should be expected in thermally processed 
products with Monascus pigments - as an example, smoked, dried or autoclaved products.

The effect of the $\mathrm{pH}$ is equally clear: when several samples were incubated at the same temperature but with different $\mathrm{pH}$ values, in the range from 4 to
8 , it was observed that in smaller pH's the color degradation is more significant. This effect is illustrated in Fig. 6.

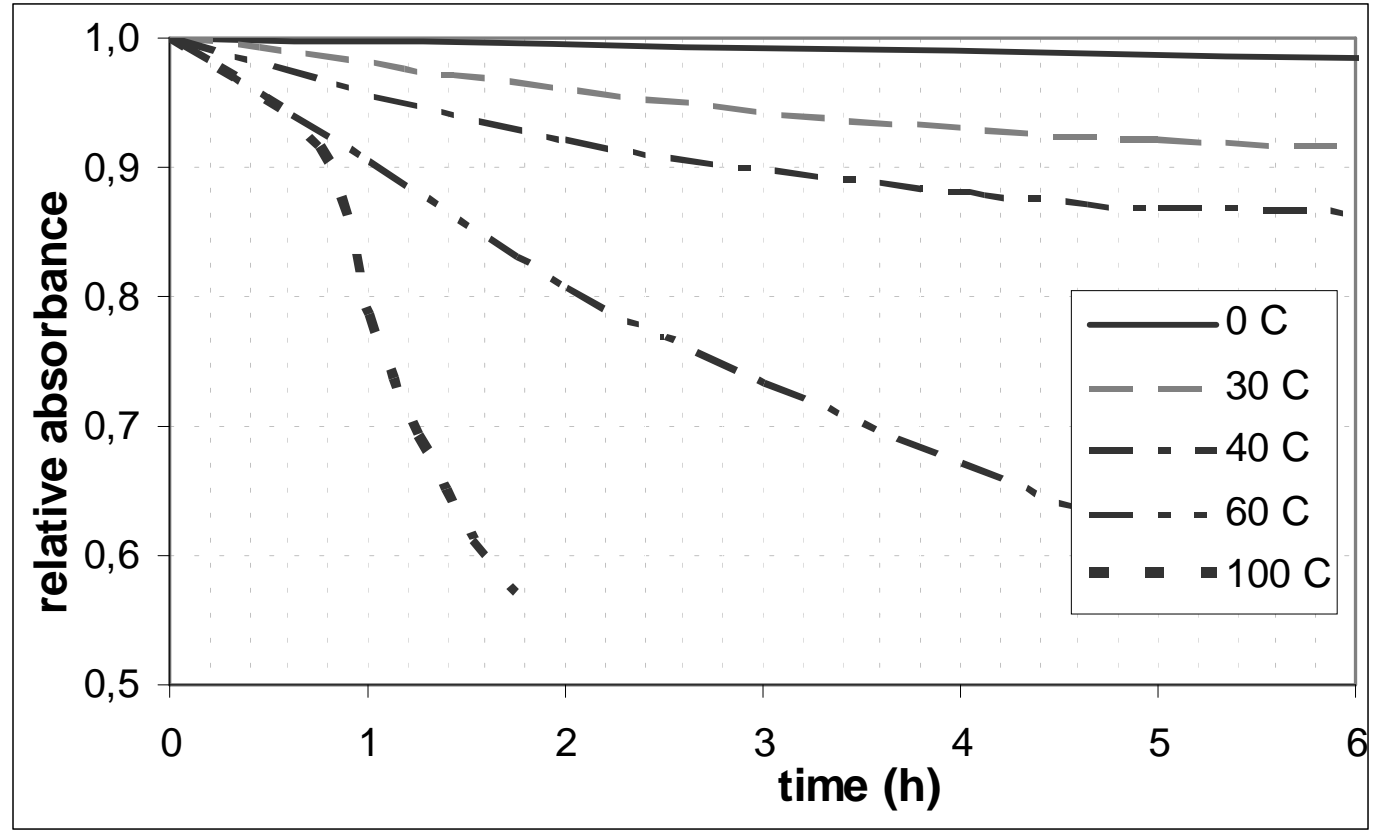

Figure 5 - Color variation (measured as relative absorbance) with time (in $\mathrm{h}$ ) for aqueous pigment solutions, at different incubation temperatures, with $\mathrm{pH} 6$.

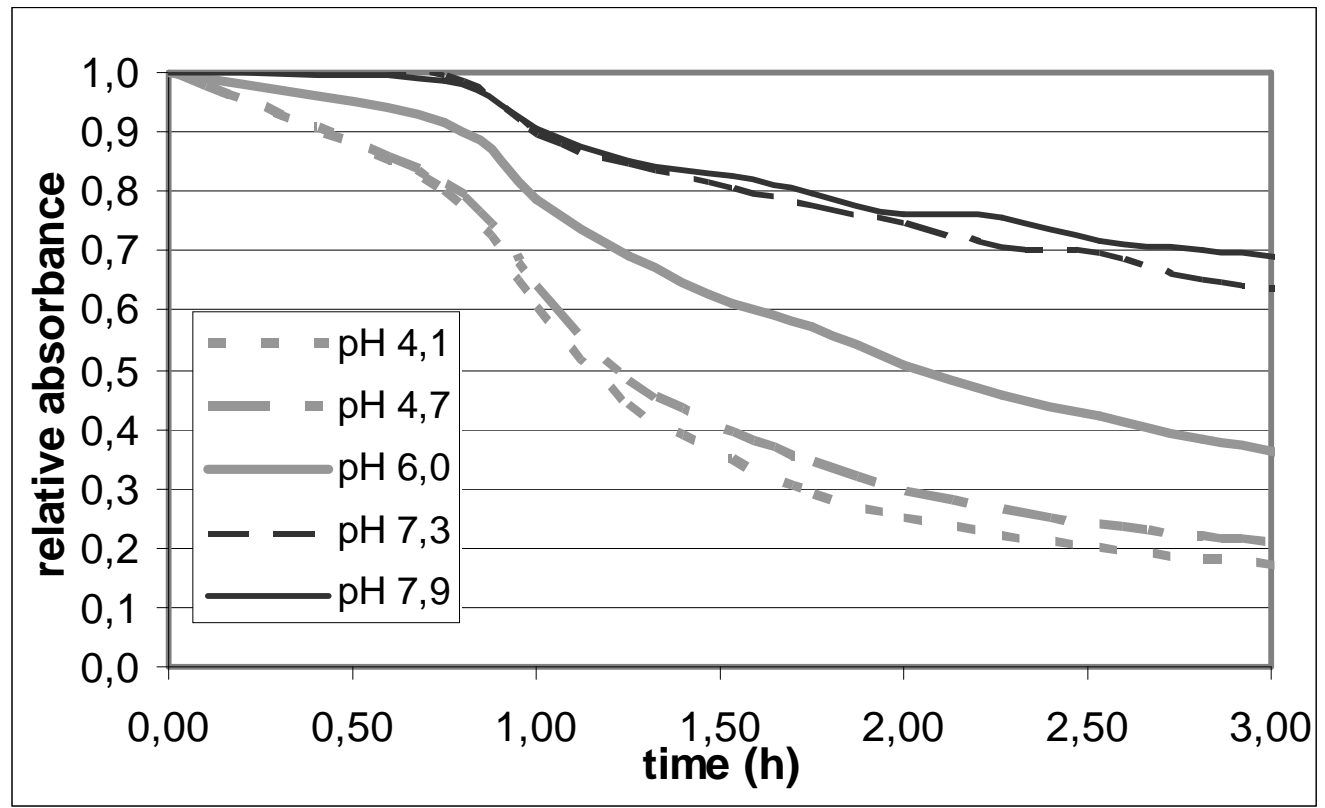

Figure 6 - Color variation (measured as relative absorbance) with time (in h) at different $\mathrm{pH}$ values, at $100^{\circ} \mathrm{C}$ 
Fig. 6 shows that the color decreases more rapidly in low $\mathrm{pH}$ values. This effect may pose a problem for application of Monascus pigments in acid foods, such as fermented milks. This effect may be due to the acid acceleration of water interaction with pigments, such as breaking of an ester linkage in rubropunctamine or monascorubramine; this effect is confirmed when an stability analysis is made with pigments in ethanol: when incubating ethanolic solutions of the pigments in the same conditions as aqueous solutions, no significant decrease in color was observed.

The effect of $\mathrm{pH}$ and temperature in residual color is summarized in the following table (Table 4). In an attempt to stabilize the pigments, several solutions at $\mathrm{pH} 7,0$ with different solutes such as the antioxidant ascorbic acid, oxidizing salts of
$\mathrm{Fe}^{3+}$ and $\mathrm{Cu}^{2+}$, and peptone (to provide complex amino compounds, present in proteins) were tested; none of these factors contributed appreciably to the stabilization of these pigments. In brief, the results indicate that there is an important decrease in color for all $\mathrm{pH}$ 's, at temperatures above $60^{\circ} \mathrm{C}$, and that in higher $\mathrm{pHs}$ (near neutrality), the pigment is more stable. These results are in accordance with those reported by Fabre (1993) and Lee (2000). Color degradation is common for natural pigments, and is therefore a major concern in coloring foods, frequently compensated by proper dosage of the pigment. Despite its poor stability, Monascus compares well with other natural pigments, so that these pigments are still a promising color additive.

Table 4 - Residual color (in \%) of aqueous pigment solutions, after $25 \mathrm{~h}$ incubation at several pH's and temperatures.

\begin{tabular}{cccccc}
\hline & \multicolumn{5}{c}{ Temperature, ${ }^{\mathbf{0}} \mathbf{C}$} \\
\hline $\mathbf{p H}$ & $\mathbf{0}$ & $\mathbf{3 2}$ & $\mathbf{4 0}$ & $\mathbf{6 0}$ & $\mathbf{1 0 0}$ \\
$\mathbf{4 , 1}$ & 80 & 86 & 79 & 49 & 13 \\
$\mathbf{4 , 7}$ & 87 & 89 & 82 & 46 & 15 \\
$\mathbf{6 , 0}$ & 83 & 87 & 81 & 57 & 16 \\
$\mathbf{7 , 3}$ & 83 & 84 & 86 & 72 & 27 \\
$\mathbf{7 , 9}$ & 84 & 92 & 88 & 79 & 53 \\
\hline
\end{tabular}

\section{CONCLUSIONS}

The results obtained show that the isolate LPB 31 is a Monascus sp strain with growth ability equivalent or superior to other tested strains, either in cassava bagasse or in rice, in glass flasks. The amount of citrinin produced by this strain is inferior to the amount found in a commercial standard. The pigment production and the productivity were superior to other strains, except the commercial sample (with a production $13 \%$ smaller), so that it may be concluded that the strain LPB 31 is adequate for the industrial production of Monascus biopigments over rice. Therefore, this strain was selected for subsequent assays, regarding the development of bioprocesses for production of red biopigments.

The biopigments obtained by Monascus were assayed for its stability towards $\mathrm{pH}$ and temperature, and it was found that these pigments are unstable at low pH's and high temperatures, so that they should be used in applications in processes with temperatures inferior to $60^{\circ} \mathrm{C}$ and pH's near neutrality. This pigment is especially adequate for application in dry or refrigerated foods, in which case color degradation is low, or in alcoholic beverages, in which the color degradation may not be observed in several months.

\section{RESUMO}

Fungos do gênero Monascus são uma fonte promissora de corantes vermelhos naturais. No entanto, antes de se aplicar Monascus a alimentos, é importante selecionar linhagens capazes de produzir grandes quantidades de pigmentos, com o mínimo possível de citrinina. Além disso, a estabilidade de cor desses pigmentos deve ser adequadamente investigada. Com o objetivo de comparar linhagens de Monascus para a produção de biopigmentos em fermentação em substrato sólido (FSS), 4 linhagens (NRRL 1991, NRRL 2897, CCT 3802 e LPB 31) foram cultivadas sobre PDA em placas de Petri, e comparadas com relação à velocidade de crescimento radial. Além disso, essas linhagens foram cultivadas em arroz cozido, e comparadas quanto à sua capacidade de produção de biopigmentos e de citrinina. Os 
resultados mostram que a linhagem LPB 31 é a melhor linhagem para produção de biopigmentos em FSS, dando tanto maior concentração de pigmentos quanto menor concentração de citrinina, mostrando que se trata de uma linhagem promissora para a obtenção deste bioproduto. Os biopigmentos extraídos dos substratos fermentados foram testados quanto à estabilidade frente ao calor e ao $\mathrm{pH}$, mostrando que os biopigmentos de Monascus são instáveis em pH's baixos e altas temperaturas, mas que podem ser usados sem problema em condições de neutralidade, em alimentos sem processamento térmico.

\section{REFERENCES}

Allok and CO (2003), Disp. in: http://www.allok.com. Access in: 10 oct. 2003.

ATCC (American Type Culture Collection) (1987), Catalogue of Fungi/Yeasts. $17^{\text {th }}$ ed. Maryland: ATCC.

ATCC (American Type Culture Collection) (2004), Online catalog. Disp. in: http://www.atcc.org. Access in: 03 sept. 2004.

Betina, V. (Ed.) (1984), Mycotoxins - production, isolation, separation and purification. Amsterdam: Elsevier. pp. 217-236.

Blanc, P. J.; Loret, M. O. and Goma, G. (1995), Production of citrinin by various species of Monascus Biotech. Lett., 17 : (3), 291-294.

Blanc, P. J.; Laussac, J. P. and Goma, G. (1995a), Characterization of monascidin A from Monascus as citrinin. Int. J. Food Microbiol., 27, 201-213.

Carvalho J. C., (2004), Desenvolvimento de bioprocesso para a produção de pigmentos a partir de Monascus por fermentação em substrato sólido. Tese (Doutorado), UFPR, Brasil.

Broder, C. V. and Koehler, P. E. (1980), J. Food Sci., 45, 567-569.

Chiu, S. W. and Poon, Y. K. (1993), Submerged production of Monascus pigments. Mycologia, 85 : (2), 214-218.

Fabre, C. E.; Goma, G. and Blanc, P. J. (1993), Production and food applications of the red pigments of Monascus ruber. J. Food Sci., 58 : (5), 1099-1110.

Johns M. R. and Stuart D. M. (1991), Production of pigments by Monascus purpureus in solid culture. $J$. Ind. Microbiol., 8, 23-38.

Jůzlová, P.; Martínková, L. and Křen, V. (1996), Secondary metabolites of the fungus Monascus: a review. J. Ind. Microbiol., 16, 163-170.

Kim, H. J.; Kim, J. H.; Oh, H. J. and Shin, C. S. (2002), Morphology control of Monascus cells and scale-up of pigment fermentation. Proc. Biochem., 38, 649-655.
Lee, Y. K. and Chen, D. C. (2000), Applications of Monascus pigments as food colorant. Disp. in: http://www.allok.com/literature. Access in: oct. 2000.

Lin, T. F. and Demain, A. L. (1992), Formation of water-soluble Monascus red pigments by biological and semi-synthetic processes. J. Indl. Microbiol., 9, 173-179.

Ma, J.; Li, Y.; Ye, Q.; Li, J.; Hua, Y.; Ju, D. and Zhang, D. (2000), Constituents of red yeast rice, a traditional chinese food and medicine. J. Agric. Food Chem., 48, 5220-5225.

The Merck Index (1996), $12^{\text {th }}$ ed. New Jersey: Merck and Co., Inc.

Miyake, T.; Ohno, S. and Sakai, S. (1984), Process for the production of Monascus-pigment. US Patent 4,442,209.

Miyashira, G. Y.; Rodrigues, R. and Kilikian, B. V. (2003), Seleção de linhagens de Monascus sp. para cultivo em meio semi-sólido. In: Congresso SINAFERM, Florianópolis. Anais ... Florianópolis.

Pitt, J. I. and Hocking A. D. (1997), Fungi and food spoilage. $2^{\text {nd }}$ ed. London: Chapman and Hall.

Rosenblitt, A.; Agosin, E.; Delgado, J. and Correa R. P. (2000), Solid substrate fermentation of Monascus purpureus: growth, carbon balance, and consistency analysis. Biotechnol. Prog., 16, 152-162.

Santerre, A. L. et al. (1994), Biotechnol. Tech., 8, 319-324.

Sheperd, D. and Carels, M. S. C. (1979), Red pigment production. US Patent 4,145,254.

Watanabe, T.; Yamamoto, A.; Nagai, S. and Terabe, S. (1997), Separation and determination of Monascus yellow pigments for food by micellar electrokinetic chromatography. Analyt. Sci., 13, 571-575.

Wong, H. C. and Koehler, P. (1981) Production and isolation of an antibiotic from Monascus purpureus and its relationship to pigment production. J. Food Sci., 46, 589-592.

Yamaguchi, Y. et al. (1973), S Patent 3,765,906.

Yongsmith, B.; Tabloka, W.; Yongmanitchai, W. and Bavavoda R. (1993), Culture conditions for yellow pigment formation by Monascus sp. KB 10 grown on cassava medium. World J. Microbiol. Biotechnol., 9, 85-90.

Received: September 23, 2004; Revised: April 08, 2005; Accepted: August 03, 2005. 